\title{
Optimum insulation thickness for the sandwich structure livestock buildings external envelopes in different climate regions of China
}

\author{
Yang Wang ${ }^{1,2,3}$, Baoming $\mathrm{Li}^{1,2,3}$, Weichao Zheng ${ }^{1,2,3^{*}}$ \\ (1. College of Water Resources and Civil Engineering, China Agricultural University, Beijing 100083, China; \\ 2. Key Laboratory of Agricultural Engineering in Structure and Environment, Ministry of Agriculture and Rural Affairs, \\ Beijing 100083, China; 3. Beijing Engineering Research Center for Animal Healthy Environment, Beijing 100083, China)
}

\begin{abstract}
Determining the optimum insulation thicknesses of external envelopes for livestock buildings are one of the most effective metrics to decrease energy requirements. This study was carried out to determine the optimum insulation thicknesses for livestock buildings in different climate zones, to examine the effects of insulation thickness and material (foam glass, mineral wool, expanded polystyrene, foamed polyurethane, foamed polyvinyl chloride, and expanded polyethylene) on life cycle total cost, life cycle savings, and payback period. The finishing pig houses and laying hen buildings with sandwich wall structures (color steel laminboard) in five typical cities were studied using the degree-days method with economic models. Optimal insulation thicknesses ranged from $0.05 \mathrm{~m}$ to $0.25 \mathrm{~m}$ and $0.02 \mathrm{~m}$ to $0.24 \mathrm{~m}$ in finishing pig houses and poultry buildings, respectively; the life cycle total costs ranged from 16.49 to $37.98 \$ / \mathrm{m}^{2}$ and 13.37 to $36.84 \$ / \mathrm{m}^{2}$; the life cycle savings ranged from 29.13 to $220.60 \$ / \mathrm{m}^{2}$ and 0 to $202.13 \$ / \mathrm{m}^{2}$; and the payback period ranged from 1.11 to 5.81 years and 1.19 to 20.76 years, respectively. Foamed polyurethane provided the highest life cycle savings, while foam glass had the lowest. In this research, the insulation thicknesses for the sandwich structure livestock buildings external envelopes are optimized, and the energy saving can be obtained by using proper insulation thickness in different regions. Furthermore, it can increase the knowledge about energy consumption in the livestock buildings and the results can be also a useful tool for farmers.

Keywords: livestock building, insulation material, optimum insulation thicknesses, degree-days, life cycle total cost, life cycle saving, payback period

DOI: $10.25165 /$ j.ijabe.20201301.5280
\end{abstract}

Citation: Wang Y, Li B M, Zheng W C. Optimum insulation thickness for the sandwich structure livestock buildings external envelopes in different climate regions of China. Int J Agric \& Biol Eng, 2020; 13(1): 29-41.

\section{Introduction}

Farm animals are usually kept in confined structures, the thermal comfort environment in such structures is crucial to animal's health, welfare, and productivity. The animal houses protect the inner space from extreme weather conditions and dampen large fluctuations in temperature ${ }^{[1]}$, and animals have limited capacity to adapt to these environments ${ }^{[2]}$. Thus, livestock building design is of great importance in providing suitable living environments and increasing livestock production efficiency ${ }^{[3-6]}$. A major part of the energy consumption of livestock buildings is due to conductive heat transfer through building surfaces, such as walls, windows, roof and foundations ${ }^{[7]}$. Reducing livestock buildings heat loads (e.g., gain in summer and loss in winter) by optimizing the thermal insulation thicknesses of building envelopes offers an effective way to ensure thermal comfort environment and meanwhile significantly decrease the energy requirements.

Studies have been conducted to determine the optimum thermal insulation thicknesses of external envelopes in residential buildings, each taking a different approach to calculate the thermal

Received date: 2019-07-10 Accepted date: 2019-11-30

Biographies: Yang Wang, $\mathrm{PhD}$ candidate, research interests: animal environment control, Email: wangyang512@cau.edu.cn; Baoming Li, PhD, Professor, research interests: animal housing, environment, equipment and animal welfare, Email: libm@cau.edu.cn.

*Corresponding author: Weichao Zheng, PhD, Associate Professor, research interests: animal environment control and welfare, China Agricultural University, Beijing 100083, China. Tel: +86-10-62736181; Email: weichaozheng@ cau.edu.cn. performance of envelopes ${ }^{[8-10]}$. The optimum insulation thickness computations were performed based on the heating and cooling loads and finical analysis methods ${ }^{[10]}$. To estimate the heating and cooling energy requirements of a building, one of the commonly used methods is the degree-time concept ${ }^{[9]}$. Several finical methods were used to optimize the thermal insulation thicknesses of external envelopes, such as the simple payback period method, life cycle cost analysis, and $\mathrm{P}_{1}-\mathrm{P}_{2}$ method $^{[8,11,12]}$. The simple payback period method is based on the time required to repay the initial capital investment with the operating savings attributed to that investment, and the main drawback is that it does not consider the time value of money, which is an important financial consideration $^{[3]}$. Several studies used life cycle cost method to calculate the cost of a system, but this method does not take into account that additional capital is invested after the initial investment (e.g., equipment, maintenance, and operation costs) ${ }^{[3,11]}$. The more commonly used method is $\mathrm{P}_{1}-\mathrm{P}_{2}$ method to calculate the net energy saving, $P_{l}$ is the life cycle energy relationship with the market interest rate, inflation rate, and the economic analysis period or the technical lifetime of the applied insulation in years ${ }^{[3]}, P_{2}$ is the ratio of the life cycle expenditures from additional capital investment to the initial investment, the $\mathrm{P}_{1}-\mathrm{P}_{2}$ economic method was proposed by Duffie and Bechman ${ }^{[12]}$.

Annual heating and cooling loads at different base temperatures were calculated for various cities in the first climatic zone of Turkey, when Bolattürk ${ }^{[11]}$ studied the optimum insulation thicknesses for building walls in Turkey. Ekici et al. ${ }^{[10]}$ investigated the optimum insulation thicknesses of various types of 
external envelopes with respect to different materials, fuels, and climate zones in Turkey. Using the optimum insulation thickness in buildings can significantly decrease the long-term energy use and costs ${ }^{[13]}$. However, the parameters of optimum insulation thicknesses for civil buildings cannot be directly used in livestock buildings. The cooling and heating energy consumptions calculated by using current degree-time method results are not quite consistent with the actual operation periods of livestock cooling and heating systems ${ }^{[6]}$. The reasons for this are, firstly, the solar radiation absorbed by the large external surfaces of livestock buildings is transmitted to the inner surfaces by conduction. Meanwhile, thermal convection occurs between outside air and the outer surface of walls, and between the inner surface and indoor air ${ }^{[14]}$. The solar radiation is neglected in cooling and heating degree-days in residential buildings. Solar radiation should be taken into consideration in livestock buildings because the areas of surfaces for livestock buildings are typically larger than residential buildings. Secondly, livestock buildings usually adopt the standards of residential buildings cooling and heating degree days. The temperature is $26^{\circ} \mathrm{C}$ for cooling and $18^{\circ} \mathrm{C}$ for heating in residential buildings, but different animals have different optimal internal calculation parameters ${ }^{[6]}$. Finally, the structure of the external envelopes is different from civil buildings, and the optimum insulation thicknesses for civil buildings cannot be directly used in livestock buildings. Civil buildings are dominated by brick and concrete structures in China, but about 95\% of livestock houses have sandwich structures (color steel laminboard) in rebuilt and new buildings in China ${ }^{[7]}$. Therefore, more appropriate values of degree-days are required for livestock buildings.

The China Statistics Yearbook data for $2017^{[5]}$ showed that the annual requirements for meat, eggs, and milk increased by approximately $3.16 \%, 2.30 \%$, and $8.43 \%$, respectively, from 1996 to 2017. Reducing energy consumption is neglected in most livestock building applications, although energy saving is usually achieved by increasing the thermal insulation thicknesses of the building envelopes to decreasing the heating and cooling loads ${ }^{[7]}$. The energy efficiency in confined livestock buildings remains low because the thermal insulation thickness is random and no standards have been applied for different climates ${ }^{[2]}$. As a result, inappropriate insulation materials and thicknesses are frequently used $^{[7]}$. Increasing the insulation thickness leads to lower thermal losses or gains but simultaneously increases the costs of the insulation materials, also raising the capital costs of the buildings. Moreover, when increasing the thickness of insulation, there is a point beyond which the cost of the insulation exceeds the monetary benefits of the energy saved ${ }^{[15]}$. To facilitate energy saving, it is necessary to determine the optimum values for livestock building parameters, which also maintain a comfortable thermal environment for the animals. Moreover, scarcely reports on optimum insulation thicknesses in livestock buildings. Therefore, reveal the effects of different climate regions, insulation materials, and air cooling and heating degree-days on optimum insulation thicknesses of livestock buildings, and obtain in-depth knowledge about optimum insulation thicknesses of livestock buildings envelopes is needed.

Specifically, the objectives of this paper are to (i) optimize the air cooling and heating degree-days, which solar radiation was taken into consideration; (ii) analyze the optimum insulation thicknesses, energy savings, and payback periods of typical insulation materials in livestock buildings based on $\mathrm{P}_{1}-\mathrm{P}_{2}$ method.

\section{Materials and methods}

\subsection{Cooling degree-days (SCDD ${ }^{*}$ ) and heating degree-days (SHDD*)}

Air degree-days (SDD) are essentially the summation of temperature differences between the solar-air temperature and the indoor base temperature for animal requirements, which is mathematically similar to concepts developed by $\mathrm{Yu}$ et al ${ }^{[6]}$ and Wang et al. ${ }^{[9]}$ SDD includes SHDD ${ }^{*}$ and SCDD $^{*}$. The total number of SHDD* and SCDD* can be calculated using the following equations:

$$
\begin{aligned}
& \operatorname{SCDD}^{*}=\sum_{1}^{365}\left(t_{s}-t_{i}\right)^{+} \quad \text { for } t_{s} \geq t_{i} \\
& \mathrm{SHDD}^{*}=\sum_{1}^{365}\left(t_{i}-t_{s}\right)^{+} \text {for } t_{s} \leq t_{i}
\end{aligned}
$$

where, $t_{i}$ is the indoor base temperature required for animals, which is different for cooling and heating degree-days and for different animals, ${ }^{\circ} \mathrm{C} ; t_{s}$ is solar-air temperature $\left({ }^{\circ} \mathrm{C}\right)$, which is determined by the outside air temperature, solar radiation absorptance, and daily average solar total radiation of the envelope surface, and is calculated according to the GB 50736-2012 $2^{[16]}$.

\subsection{Optimum insulation thickness}

2.2.1 Annual cooling and heating energy consumption of external envelopes

Heat loss from livestock buildings generally occurs through building components (external walls, roof, floor, and doors), ventilation, and air infiltration. Heat loss from ventilation varies depending on the capacity of animals in the houses and was not considered in this study. In the present study, the optimum insulation thicknesses for livestock buildings were calculated by considering heat losses from external envelopes only. The outer surface of livestock buildings envelope absorbs solar radiation and transmits it to the inner surface of building. Heat loss from a unit area of an external envelope can be calculated using the following equation:

$$
q_{w}=U\left(t_{i}-t_{s}\right)
$$

where, $q_{w}$ is the heat loss per unit area of envelope, $\mathrm{W} / \mathrm{m}^{2} ; U$ is the heat transfer coefficient of the external envelope, $\mathrm{W} /\left(\mathrm{m}^{2} \cdot \mathrm{K}\right)$.

The annual heat loss per unit area of external envelope can be obtained from:

$$
Q_{h}=86400 \times U \times S H D D^{*}
$$

where, $Q_{h}$ is the annual heat loss per unit area, $\mathrm{MJ} /\left(\mathrm{m}^{2} \cdot \mathrm{a}\right)$.

The annual energy consumption for heating per unit area of external envelope can be expressed as:

$$
E_{h}=\frac{86400 \times U \times S H D D^{*}}{L H V \times \eta_{h}}
$$

where, $E_{h}$ is the annual energy consumption for heating per unit area, $\mathrm{kW} /\left(\mathrm{m}^{2} \cdot \mathrm{a}\right), \mathrm{m}^{3} /\left(\mathrm{m}^{2} \cdot \mathrm{a}\right)$, or $\mathrm{kWh} /\left(\mathrm{m}^{2} \cdot \mathrm{a}\right) ; L H V$ is the lower heating value of the fuel, $\mathrm{J} / \mathrm{kW}, \mathrm{J} / \mathrm{kg}$, or $\mathrm{J} / \mathrm{m}^{3}$, depending on the fuel type; $\eta_{h}$ is the efficiency of the heating system; 86400 is the unit conversion coefficient ${ }^{[17]}$.

Similarly, the annual cold loss per unit area of external envelope can be expressed as:

$$
Q_{c}=86400 \times U \times S C D D^{*}
$$

where, $Q_{c}$ is the annual cold loss per unit area, $\mathrm{MJ} /\left(\mathrm{m}^{2} \cdot \mathrm{a}\right)$. The annual energy consumption for cooling per unit area of external envelope can be expressed as:

$$
E_{c}=\frac{86400 \times U \times S C D D^{*}}{L H V \times \eta_{c}}
$$

where, $E_{c}$ is the annual energy consumption for heating per unit area, $\mathrm{kW} /\left(\mathrm{m}^{2} \cdot \mathrm{a}\right), \mathrm{m}^{3} /\left(\mathrm{m}^{2} \cdot \mathrm{a}\right)$, or $\mathrm{kWh} /\left(\mathrm{m}^{2} \cdot \mathrm{a}\right) ; \eta_{c}$ is the energy efficiency ratio of the cooling system. 
$U$ is the overall heat transfer coefficient of the external envelope, which includes a layer of insulation, and it can be calculated as:

$$
U=\frac{1}{R_{i}+R_{w}+R_{\text {ins }}+R_{o}}
$$

where, $R_{i}$ and $R_{o}$ are the inside and outside envelope surface thermal resistance, respectively, $\mathrm{m}^{2} /(\mathrm{K} \cdot \mathrm{W}) ; R_{w}$ is the thermal resistance of the composite sandwich wall materials without the insulation, $\mathrm{m}^{2} /(\mathrm{K} \cdot \mathrm{W}) ; R_{\text {ins }}$ is the thermal resistance of the insulation layer, $\mathrm{m}^{2} /(\mathrm{K} \cdot \mathrm{W})$, which is:

$$
R_{\text {ins }}=\frac{x}{\lambda_{\text {ins }}}
$$

where, $x$ is the thickness of insulation materials, $\mathrm{m}$; $\lambda_{\text {ins }}$ is the thermal conductivity of insulation materials, $\mathrm{W} /(\mathrm{m} \cdot \mathrm{K})$. If $R_{t w}$ is the total wall thermal resistance, excluding the insulation layer resistance, $\mathrm{m}^{2} \cdot \mathrm{K} / \mathrm{W}$, Equation (8) can be rewritten as:

$$
U=\frac{1}{R_{t w}+\frac{x}{\lambda_{\text {ins }}}}
$$

As a result, the annual heat and cold load is then given by:

$$
\begin{aligned}
& Q_{h}=\frac{86400 \times S H D D^{*}}{R_{t w}+\frac{x}{\lambda_{i n s}}} \\
& Q_{c}=\frac{86400 \times S C D D^{*}}{R_{t w}+\frac{x}{\lambda_{i n s}}}
\end{aligned}
$$

And the annual energy consumption for heating and cooling per unit area of external envelope can be rewritten as:

$$
\begin{gathered}
Q_{c}=\frac{86400 \times S H D D^{*}}{L H V \times \eta_{h} \times\left(R_{t w}+\frac{x}{\lambda_{\text {ins }}}\right)} \\
E_{c}=\frac{86400 \times S C D D^{*}}{L H V \times \eta_{h} \times\left(R_{t w}+\frac{x}{\lambda_{\text {ins }}}\right)}
\end{gathered}
$$

\subsubsection{Optimum insulation thickness and energy savings}

The $\mathrm{P}_{1}-\mathrm{P}_{2}$ economic method was proposed by Duffie and Bechman ${ }^{[12]}$, and $\mathrm{P}_{1}$ can be calculated using the following equation $^{[3,18,19]}$ :

$$
P_{1}=\sum_{j=1}^{N_{e}} \frac{(1+i)^{j-1}}{(1+d)^{j}}=\left\{\begin{array}{cc}
\frac{1}{(d-i)}\left[1-\left(\frac{1+i}{1+d}\right)^{N_{e}}\right] & i \neq d \\
\frac{N_{e}}{1+i} & i=d
\end{array}\right.
$$

where, $i$ and $\mathrm{d}$ are the interest rate and inflation rate, $\%$, the values are $5 \%$ and $8 \%{ }^{[8]}$, respectively; $N_{e}$ is the economic analysis period or the technical lifetime of the applied insulation in years.

The ratio of the life cycle expenditures from additional capital investment to the initial investment $\left(P_{2}\right)$, which can be calculated as:

$$
P_{2}=1+M_{s} P_{1}-\frac{R_{v}}{(1+d)^{N_{e}}}
$$

where, $M_{s}$ is the ratio of the annual maintenance and operation costs to the original cost; $R_{v}$ is the ratio of the resale value at the end of the analysis period to the first cost.

The insulation cost per unit area can be determined from the following equation:

$$
C_{\text {ins }}=C_{i} x+P_{c}
$$

where, $C_{i n s}$ is the insulation cost per unit area, $\$ / \mathrm{m}^{2} ; C_{i}$ is the price of insulation material, $\$ / \mathrm{m}^{3} ; P_{c}$ is all other costs per unit area, $\$ / \mathrm{m}^{2}$.

The life cycle total cost (LCTC) is the sum of the cost of insulation material and the energy consumption over the lifetime of the livestock buildings, it is can be written as:

$$
\begin{aligned}
L C T C= & P_{1} C_{f}\left(\frac{86400 \times S H D D^{*}}{L H V \times \eta_{h} \times\left(R_{t w}+\frac{x}{\lambda_{\text {ins }}}\right)}+\frac{86400 \times S C D D^{*}}{L H V \times \eta_{c} \times\left(R_{t w}+\frac{x}{\lambda_{\text {ins }}}\right)}\right)+ \\
& P_{2}\left(C_{i} x+P_{c}\right)
\end{aligned}
$$

where, $C_{f}$ is the fuel cost, $\$ /(\mathrm{kW} \cdot \mathrm{h})$.

The life cycle savings (LCS) per unit area is calculated as the difference between the energy saving over the lifetime and the insulation material cost, the life cycle savings corresponding to the optimum insulation thickness, can be written as:

$$
\begin{aligned}
L C S= & P_{1} C_{f}\left(\frac{86400 \times \Delta U \times S H D D^{*}}{L H V \times \eta_{h}}+\frac{86400 \times \Delta U \times S C D D^{*}}{L H V \times \eta_{c}}\right)- \\
& P_{2}\left(C_{i} x+P_{c}\right)
\end{aligned}
$$

where, $\Delta U$ is the difference between the heat transfer coefficient without insulation and with insulation, $\mathrm{W} /\left(\mathrm{m}^{2} \cdot{ }^{\circ} \mathrm{C}\right)$. It can be written as:

$$
\Delta U=\frac{1}{R_{i}+R_{w}+R_{o}}-\frac{1}{R_{i}+R_{w}+R_{\text {ins }}+R_{o}}
$$

The optimum insulation thickness is the value of $x$ which minimizes the LCTC and is obtained by minimizing Equation (18) or maximizing Equation (19). Hence, the value is calculated by setting the derivative of LCTC with respect to $x$ equal to zero, and the optimum insulation thickness $x_{o p}$ is determined as:

$$
x_{o p}=293.94 \sqrt{\frac{P_{1} C_{f} \lambda_{i n s}}{(L H V) P_{2} C_{i}}\left(\frac{S H D D^{*}}{\eta_{h}}+\frac{S C D D^{*}}{\eta_{c}}\right)}-R_{t w} \lambda_{i n s}
$$

From Equation (21), it can be seen that optimum insulation thickness depends on air degree-days, fuel cost, insulation material cost, interest rate, inflation rate, lifetime, fuel, and insulation material properties. When the inflation and the interest rates are taken into account, the payback period can be calculated as follows:

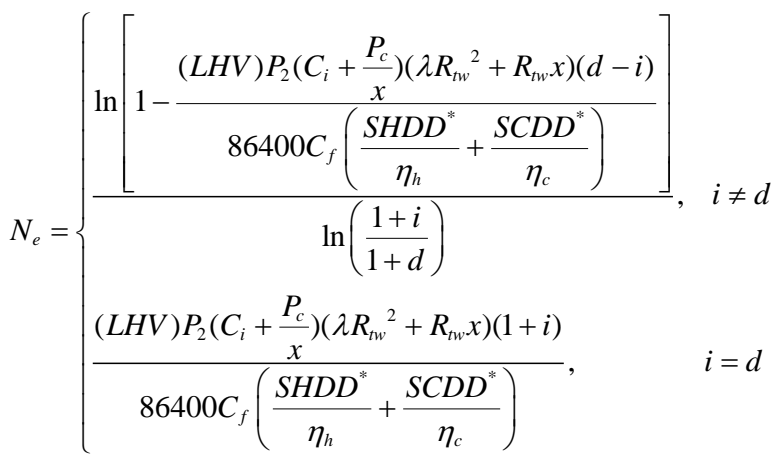

\subsection{Climate zones and animal information}

Five major climates zones, defined as severe cold, cold, temperate, hot summer and cold winter, and hot summer and warm winter (Figure 1) in China. Five typical cities were selected to represent the five climate zones: Harbin $\left(45.75^{\circ} \mathrm{N}, 126.76^{\circ} \mathrm{E}\right.$, severe cold), Beijing $\left(39.8^{\circ} \mathrm{N}, 116.46^{\circ} \mathrm{E}\right.$, cold), Chongqing $\left(29.58^{\circ} \mathrm{N}, 106.46^{\circ} \mathrm{E}\right.$, hot summer and cold winter), Kunming $\left(25.01^{\circ} \mathrm{N}, 102.68^{\circ} \mathrm{E}\right.$, temperate) and Guangzhou $\left(23.16^{\circ} \mathrm{N}\right.$, $113.33^{\circ} \mathrm{E}$, hot summer and warm winter). Thus, the results for these selected cities may be conveniently used to obtain reasonable estimates of optimal thermal insulation thicknesses for other cities within the different climate zones ${ }^{[20]}$. The number of laying hens 
and finishing pigs in China is among the highest in the world ${ }^{[10,7]}$. Laying hens and finishing pigs were selected to determine the optimum insulation thicknesses, and the optimum production temperature and base temperature for poultry and finishing pigs as shown in Table $1^{[21]}$.

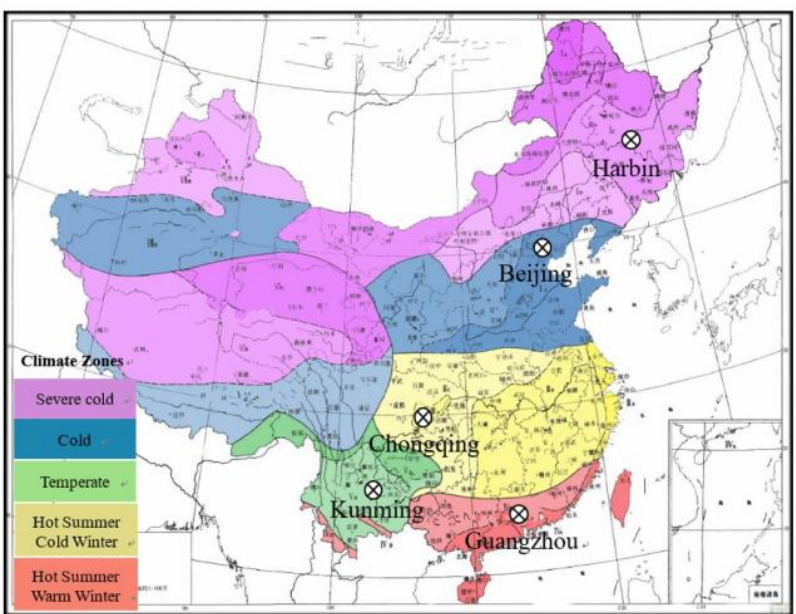

Figure 1 Climate zones of China and the five cities selected for this study

Table 1 Optimum production temperature and base temperature for poultry and finishing pigs

\begin{tabular}{cccc}
\hline Animals & $\begin{array}{c}\text { Optimum } \\
\text { temperature } /{ }^{\circ} \mathrm{C}\end{array}$ & $\begin{array}{c}\text { Base temperature for } \\
\text { cooling } /{ }^{\circ} \mathrm{C}\end{array}$ & $\begin{array}{c}\text { Base temperature for } \\
\text { heating } /{ }^{\circ} \mathrm{C}\end{array}$ \\
\hline $\begin{array}{c}\text { Laying hen } \\
(150-400 \mathrm{~d})\end{array}$ & $18-24$ & 24 & 18 \\
$\begin{array}{c}\text { Finishing pig } \\
(120-180 \mathrm{~d})\end{array}$ & $12-18$ & 18 & 12 \\
\hline
\end{tabular}

\subsection{Structure of the building external envelopes}

The sandwich structure was used in the calculations for the analyzed cities ${ }^{[7]}$. The sandwich wall consists of an insulation layer between two plaster layers on the inside and outside surfaces. The structure of the color steel laminboard consists of $0.20 \mathrm{~mm}$ external plaster (light, mid, and deep color surface), insulation material, and $0.20 \mathrm{~mm}$ inner plaster (Figure 2). There are six main types of insulation, namely foam glass, mineral wool, expanded polystyrene, foamed polyurethane, foamed polyvinyl chloride, and expanded polyethylene. The properties of these insulation materials are given in Table $2^{[22]}$, and the lifetime is 20 years ${ }^{[23]}$. Modern confined livestock houses are typically equipped with tunnel ventilation and wet-pad evaporative cooling systems in summer and electric heaters in winter ${ }^{[7]}$, which are controlled by electricity. Thus, in this study, calculations were only carried out for energy type-electricity, and the energy efficiency ratios of the cooling and heating systems are shown in Table $3^{[16]}$. The corresponding values for parameters used to calculate the optimum insulation thickness, payback period, and energy saving are given in Table $4^{[6,7,14,16]}$.
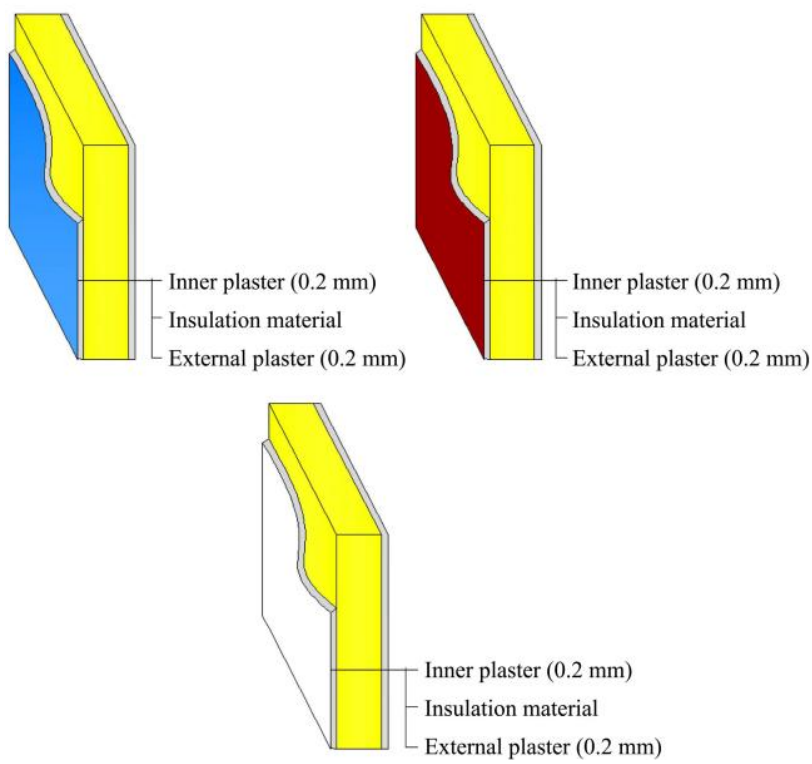

Figure 2 Structure of color steel laminboard. The structure of color steel laminboard consists of $0.2 \mathrm{~mm}$ external plaster, insulation material, and $0.2 \mathrm{~mm}$ inner plaster

Table 2 Parameters of the properties for the six main types of insulation materials

\begin{tabular}{lcccc}
\hline \multicolumn{1}{c}{ Insulation material } & $\rho / \mathrm{kg} \cdot \mathrm{m}^{-3}$ & $\lambda_{\text {ins }} / \mathrm{W} \cdot \mathrm{m}^{-1} \cdot \mathrm{K}^{-1}$ & Specific heat $/ \mathrm{J} \cdot \mathrm{kg}^{-1} \cdot{ }^{\circ} \mathrm{C}^{-1}$ & $C_{i} / \$ \cdot \mathrm{m}^{-3}$ \\
\hline Foam glass & 140 & 0.06 & 1220 & 32.80 \\
Mineral wool & 80 & 0.05 & 1220 & 0.70 \\
Expanded polystyrene & 30 & 0.04 & 1380 & 0.59 \\
Foamed polyurethane & 30 & 0.03 & 1380 & 0.36 \\
Foamed polyvinyl chloride & 130 & 0.05 & 1380 & 0.36 \\
Expanded polyethylene & 100 & 0.05 & 1380 & 0.79 \\
\hline
\end{tabular}

Table 3 Parameters of the energy efficiency ratio for the cooling and heating system

\begin{tabular}{cccccc}
\hline Type & Severe cold & Cold & Hot summer and cold winter & Temperate & Hot summer and warm winter \\
\hline$\eta_{c}$ & 2.65 & 2.70 & 2.75 & 2.65 & 2.75 \\
$\eta_{h}$ & 3.25 & 3.35 & 3.40 & 3.30 & 3.45 \\
\hline
\end{tabular}

Table 4 Corresponding values for parameters used to calculate the optimum insulation thickness, payback period, and energy saving

\begin{tabular}{|c|c|c|c|}
\hline Parameter & Value & Parameter & Value \\
\hline Inside envelope surface thermal resistance $/ \mathrm{m}^{2} \cdot \mathrm{K} \cdot \mathrm{W}^{-1}$ & 0.12 & Lower heating value $/ \mathrm{J} \cdot(\mathrm{kW} \cdot \mathrm{h})^{-1}$ & $3.60 \times 10^{6}$ \\
\hline Outside envelope surface thermal resistance $/ \mathrm{m}^{2} \cdot \mathrm{K} \cdot \mathrm{W}^{-1}$ & 0.04 & $\begin{array}{l}\text { Ratio of the resale value at the end of the analysis period } \\
\text { to the first cost, Rv }\end{array}$ & 0 \\
\hline $\begin{array}{l}\text { Thermal resistance of the composite sandwich wall materials } \\
\text { without the insulation } / \mathrm{m}^{2} \cdot \mathrm{K} \cdot \mathrm{W}^{-1}\end{array}$ & 0 & All other costs per unit area $/ \$ \cdot \mathrm{m}^{-2}$ & 10 \\
\hline $\begin{array}{l}\text { Total wall thermal resistance, excluding the insulation layer } \\
\text { resistance } / \mathrm{m}^{2} \cdot \mathrm{K} \cdot \mathrm{W}^{-1}\end{array}$ & 0.16 & Fuel cost $/ \$ \cdot(\mathrm{kW} \cdot \mathrm{h})^{-1}$ & 0.08 \\
\hline $\begin{array}{l}\text { Ratio of the annual maintenance and operation costs to the } \\
\text { original cost, Ms }\end{array}$ & 0 & & \\
\hline
\end{tabular}




\section{Results and discussion}

\subsection{Cooling degree-days (SCDD*) and heating degree-days (SHDD*)}

The SHDD* and SCDD* in the selected five different cities were calculated according to Equations (1) and (2) and are shown in Tables 5 and 6. A model validation test was performed in a laying house to verify the reliability of the optimized air degree-day method by Wang et al. ${ }^{[9]}$, and it shows that the results obtained by the degree-day method are reliable and can be readily used in engineering applications under different climates. The outdoor temperatures for the design were in the range of $-24.2^{\circ} \mathrm{C}$ to $12.6^{\circ} \mathrm{C}$, and the range of the heating and cooling degree-days varied significantly from one region to another, and $\mathrm{Yu}$ et al. ${ }^{[6]}$ also reported the range of the heating and cooling degree-days. In this study, the cooling degree-days and heating degree-days is $1597^{\circ} \mathrm{C} \cdot \mathrm{d}$ and $148^{\circ} \mathrm{C} \cdot \mathrm{d}$ of light color surface of finishing pig houses in Chongqing, respectively. The cooling degree-days and heating degree-days is $550^{\circ} \mathrm{C} \cdot \mathrm{d}$ and $848^{\circ} \mathrm{C} \cdot \mathrm{d}$ respectively of light color surface of laying hen houses in Chongqing. Yu et al. ${ }^{[6]}$ calculated the cooling degree-days and heating degree-days by replacing the ambient temperature with the solar-air temperature in hot summer and cold winter zone of China, and the cooling degree-days and heating degree-days is $109^{\circ} \mathrm{C} \cdot \mathrm{d}$ and $1558^{\circ} \mathrm{C} \cdot \mathrm{d}$ of light color surface in Chengdu (hot summer and cold winter zone), respectively. The reason for the difference in the same climate zone might be caused by the different base temperatures, and the temperature is $26^{\circ} \mathrm{C}$ for cooling and $18^{\circ} \mathrm{C}$ for heating in residential buildings ${ }^{[6,14]}$, but different animals have different optimal internal calculation parameters.

Table 5 SHDD ${ }^{*}$ and SCDD ${ }^{*}$ in finishing pig houses, ${ }^{\circ} \mathrm{C} \cdot \mathrm{d}$

\begin{tabular}{ccccccc}
\hline \multirow{2}{*}{ Degree-days } & \multirow{2}{*}{$\begin{array}{c}\text { External } \\
\text { surface }\end{array}$} & \multicolumn{5}{c}{ City } \\
\cline { 3 - 7 } & Harbin & Beijing & Chongqing & Kunming & Guangzhou \\
\hline \multirow{3}{*}{ SCDD* } & Light color & 522 & 1092 & 1597 & 569 & 2345 \\
& Mid color & 801 & 1480 & 2088 & 1034 & 2973 \\
& Deep color & 1136 & 1921 & 2660 & 1583 & 3672 \\
\hline \multirow{2}{*}{ SHDD* } & Light color & 3589 & 1358 & 148 & 194 & 8 \\
& Mid color & 3140 & 1033 & 44 & 85 & 1 \\
& Deep color & 2717 & 769 & 13 & 44 & 0 \\
\hline
\end{tabular}

Note: Light color-solar radiation absorptance of 0.25 ; mid color-solar radiation absorptance of 0.50 ; deep color-solar radiation absorptance of 0.75 .

Table 6 SHDD ${ }^{*}$ and SCDD ${ }^{*}$ in laying hen houses, ${ }^{\circ} \mathrm{C} \cdot \mathrm{d}$

\begin{tabular}{ccccccc}
\hline & \multirow{5}{*}{$\begin{array}{c}\text { External } \\
\text { surface }\end{array}$} & \multicolumn{5}{c}{ City } \\
\cline { 3 - 7 } & Harbin & Beijing & Chongqing & Kunming & Guangzhou \\
\hline \multirow{3}{*}{ SCDD* $^{*}$} & Light color & 86 & 340 & 550 & 1 & 876 \\
& Mid color & 208 & 578 & 881 & 77 & 1341 \\
& Deep color & 405 & 890 & 1290 & 348 & 1879 \\
\hline \multirow{2}{*}{ SHDD* } & Light color & 4961 & 2432 & 848 & 936 & 254 \\
& Mid color & 4340 & 2040 & 548 & 626 & 122 \\
& Deep color & 3895 & 1610 & 330 & 402 & 60 \\
\hline
\end{tabular}

\subsection{Optimum insulation thickness}

\subsubsection{Impact factors analysis of insulation thickness}

The effect of degree-days on the insulation thicknesses for the six insulation materials is shown in Figure 3. The insulation thickness increased with increasing degree-days. In terms of their thermal conductivity, the insulation materials can be listed as foam glass > mineral wool > foamed polyvinyl chloride > expanded polyethylene > expanded polystyrene > foamed polyurethane. The insulation thickness increased with increasing thermal conductivity of the insulation materials. The maximum insulation thickness was obtained at higher degree-days with foam glass and mineral wool materials as these materials have the highest thermal conductivity. There seemed to be a positive correlation between the insulation thickness and the thermal conductivity of the insulation materials. The results were also observed by Ekici et al. ${ }^{[10]}$ and Mahlia et al. ${ }^{[19]}$ to investigate the insulation thicknesses for the various types of external envelopes with respect to different materials.

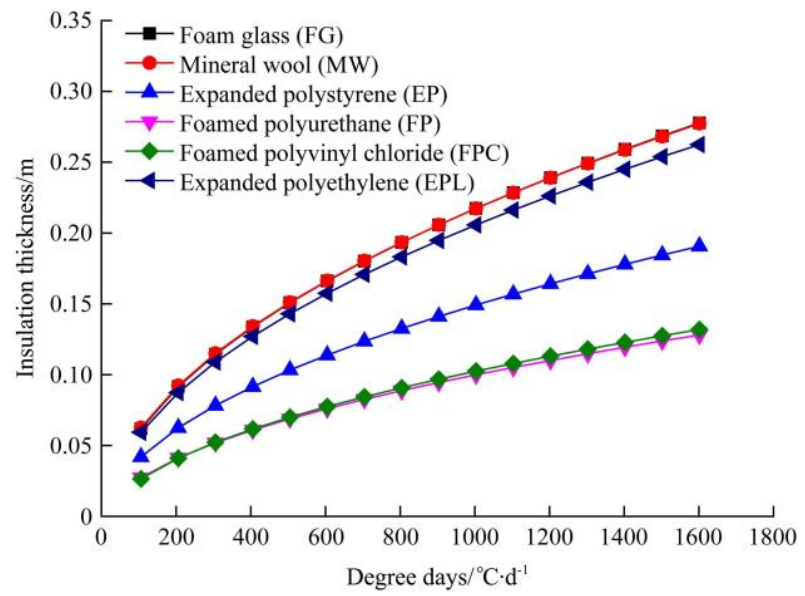

Figure 3 Effects of the degree-days on insulation thicknesses for the six insulation materials

Figure 4 shows the effect of the price of insulation material on insulation thicknesses in laying hen houses with light color surfaces in Beijing. The insulation thickness depends on the price of insulation material and the insulation type. The insulation thickness decreased as the price of the insulation materials increased. For example, using expanded polystyrene in laying hen houses, the insulation thickness changed from $0.18 \mathrm{~m}$ to $0.07 \mathrm{~m}$ when the price of the insulation material increased from $20 \$ / \mathrm{m}^{2}$ to $100 \$ / \mathrm{m}^{2}$. The insulation thickness varied between $0.06 \mathrm{~m}$ and $0.21 \mathrm{~m}$ depending on the price of the insulation material.

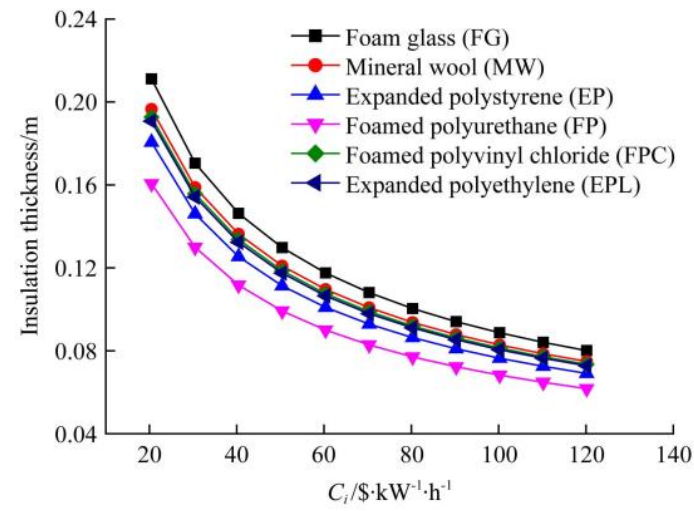

Figure 4 Effects of the price of insulation material on insulation thickness of light color surface for laying hen houses in Beijing

The effects of the insulation thickness on the LCTC of finishing pig houses with light color surfaces in five different cities are shown in Figure 5. As can be seen from Figure 5, the LCTC using foam glass and mineral wool are lower than those using expanded polystyrene, foamed polyurethane, foamed polyvinyl chloride, and expanded polyethylene, indicating that the former is more economical than the latter. The insulation thicknesses in finishing pig houses with light color surfaces in Beijing using foam 
glass, mineral wool, expanded polystyrene, foamed polyurethane, foamed polyvinyl chloride, and expanded polyethylene were $0.20 \mathrm{~m}, 0.19 \mathrm{~m}, 0.13 \mathrm{~m}, 0.09 \mathrm{~m}, 0.09 \mathrm{~m}$, and $0.19 \mathrm{~m}$, respectively. The LCTC shows a sharp initial decrease and then a gradual increase, and the insulation thickness that gives the lowest LCTC value is the optimum insulation thickness. Ekici et al. ${ }^{[10]}$ also

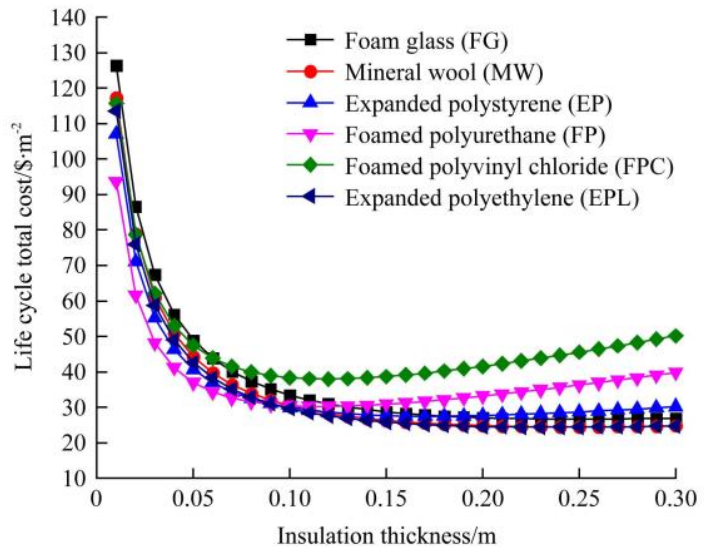

a. Harbin

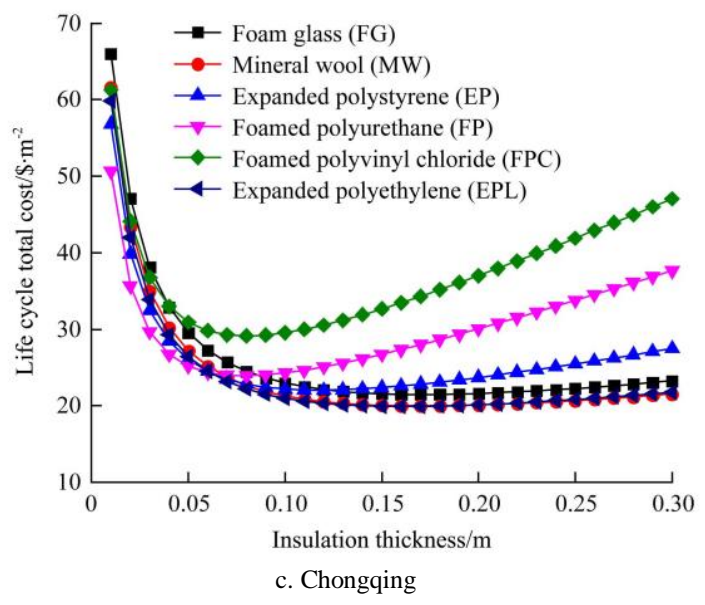

reported the effect of insulation thickness on the LCTC, and reported that the LCTC decreased until the insulation thickness was achieved. For the thickness above the thickness, the LCTC increases in line with the increase in the insulation thickness. This is due to the fact that while fuel costs decrease as a result of the increased thermal insulation, the cost of insulation materials rises.
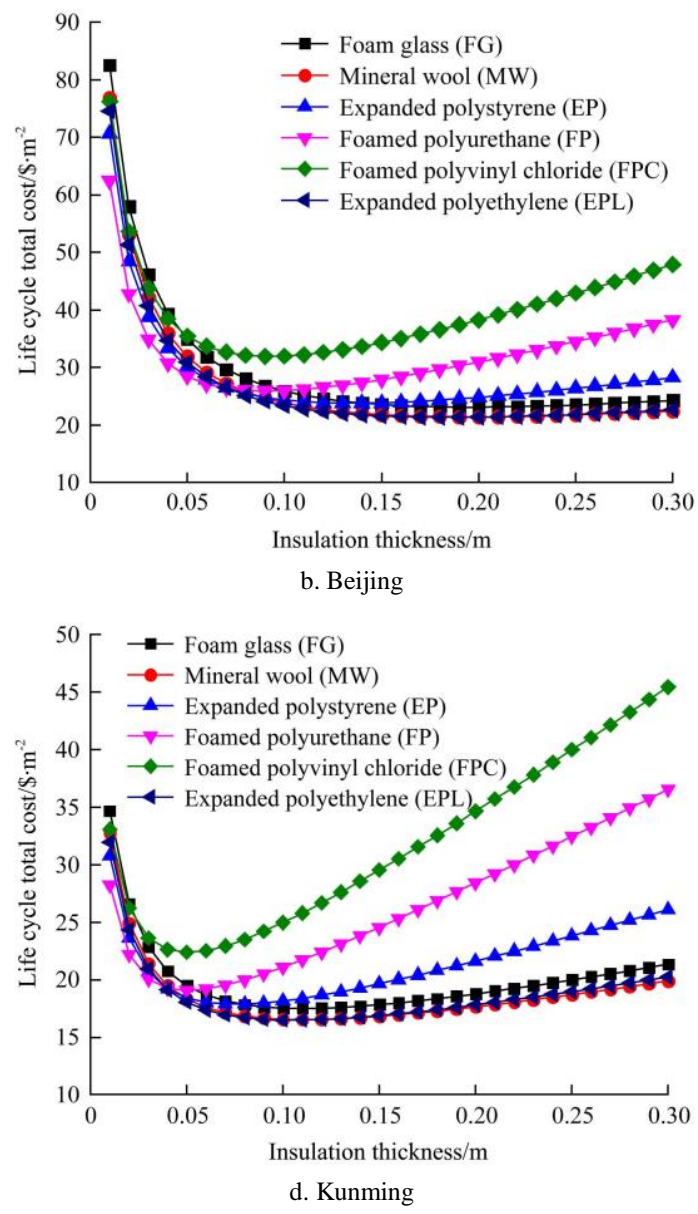

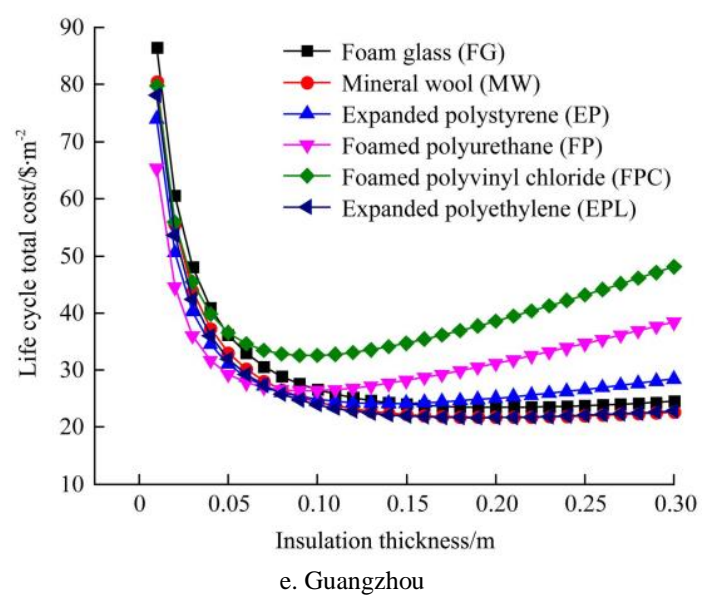

Figure 5 Effects of insulation thickness on LCTC of finishing pig houses with light color surfaces Harbin, Beijing,

Chongqing, Kunming, Guangzhou

For different insulation materials, the effect of insulation thickness on LCS for the six insulation materials in finishing pig houses with light color surface is shown in Figure 6. As insulation thickness increases, the life cycle savings increase rapidly, and then gradually level off as the insulation thickness reaches its maximum values at optimum insulation thickness. The LCS at insulation thicknesses for foam glass, mineral wool, expanded polystyrene, foamed polyurethane, foamed polyvinyl chloride, and expanded polyethylene insulation materials were 129.36\$/ $\mathrm{m}^{2}, 131.07 \$ / \mathrm{m}^{2}, 128.71 \$ / \mathrm{m}^{2}, 126.56 \$ / \mathrm{m}^{2}, 120.58 \$ / \mathrm{m}^{2}$, and $131.15 \$ / \mathrm{m}^{2}$, respectively. Life cycle savings were highest using foamed polyurethane as the insulation material, followed by expanded polystyrene, expanded polyethylene, and mineral wool. These results show that the insulation material had a notable effect on LCS because it takes into account the insulation material type and the price. The results were similar to those of 
Bolattürk $^{[11]}$ and Ekici et al. ${ }^{[10]}$ who also reported the LCS reaches its maximum value at the optimum insulation thickness, but each

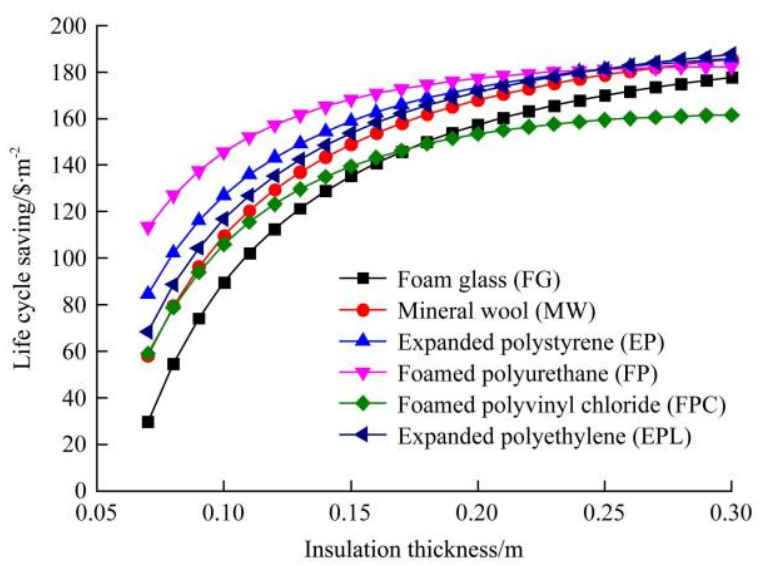

a. Harbin

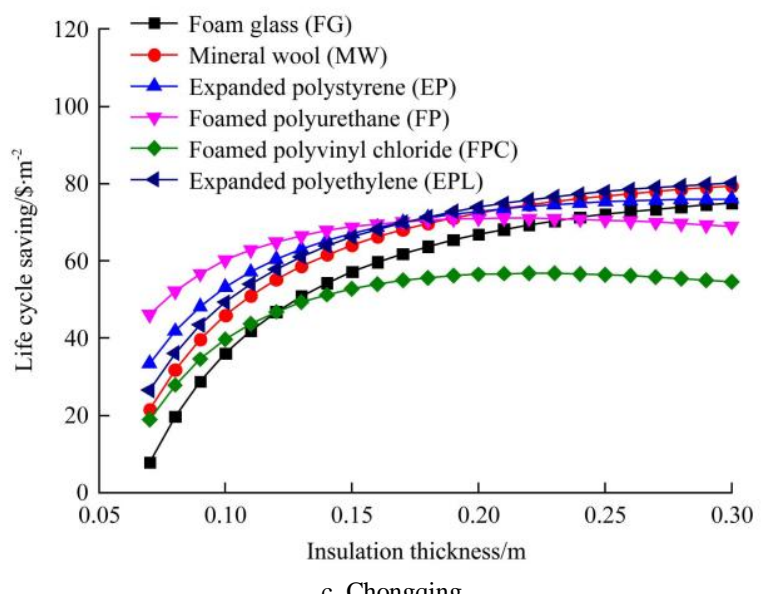

c. Chongqing of the insulation materials the optimum thickness is of a different value.

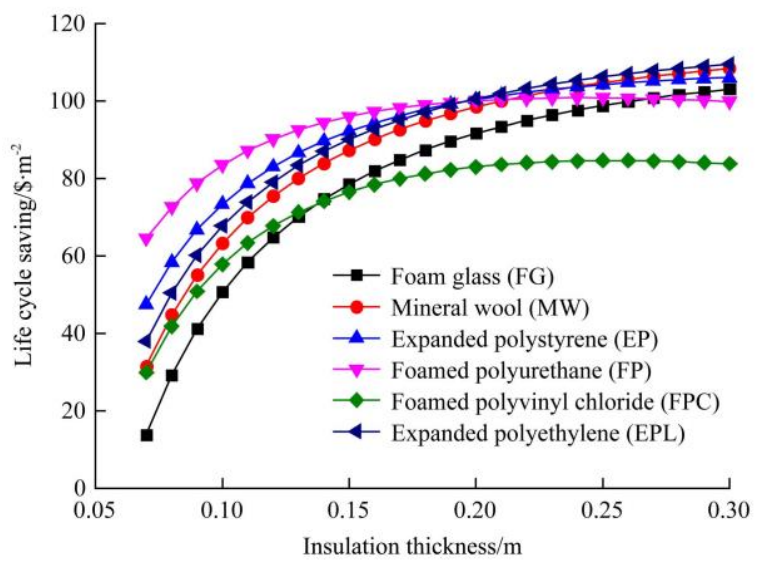

b. Beijing

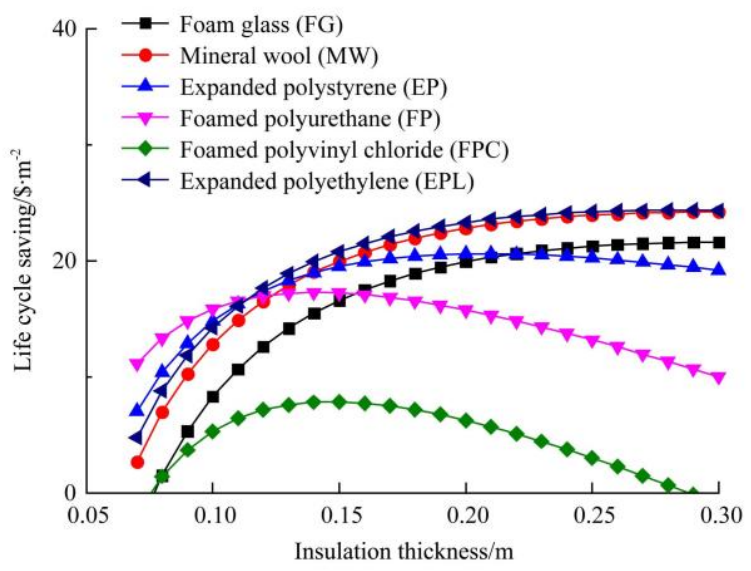

d. Kunming

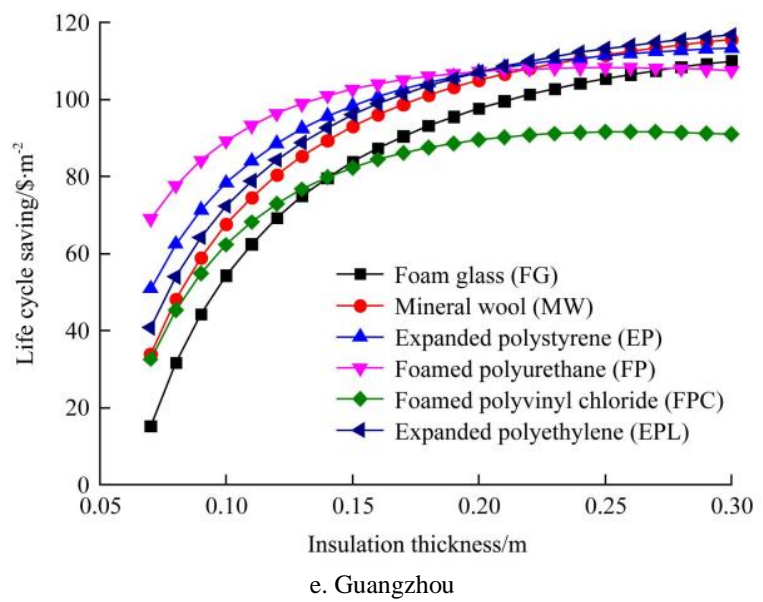

Figure 6 Effects of insulation thickness on life cycle savings of finishing pig houses with light color surface in selected five cities Harbin, Beijing, Chongqing, Kunming, Guangzhou

Payback periods of the insulation thicknesses in laying hen houses with light color surfaces are shown in Figure 7 for different insulation materials. The payback periods using foam glass and mineral wool as insulation are lower than that using foamed polyvinyl chloride as insulation. $\mathrm{Yu}$ et al. ${ }^{[6]}$ calculated the optimum insulation thicknesses of five insulation materials for a typical residential wall in four cities, and the results showed that expanded polystyrene was the most economical insulation material because it had the highest life cycle savings and lowest payback period. The payback period for different insulation materials of laying hen houses with light color surface ranged between 0.89 and
2.36 years in Harbin, 1.89 and 5.12 years in Beijing, 4.22 and 12.23 years in Chongqing, and 3.45 and 9.77 years in Guangzhou. Daouas ${ }^{[8]}$ reported that a life cycle cost analysis over a building lifetime of 30 years in Tunisian buildings, with an optimum insulation thickness of $0.10 \mathrm{~cm}$, and a payback period of 3.29 years, based on calculation of cooling and heating transmission loads; Liu et al. ${ }^{[23]}$ indicated that maximum lifecycle savings varied from $16.60 \$ / \mathrm{m}^{2}$ to $28.50 \$ / \mathrm{m}^{2}$ and the payback period varied from 1.89 to 2.56 years when the optimum insulation thickness was used. The payback period increased once the insulation thickness exceeded its optimum (Figure 7). For example, the payback 
periods for foamed polyvinyl chloride were 1.69, 3.00, 5.73, and 4.96 years for Harbin, Beijing, Chongqing, and Guangzhou, respectively, and the optimal insulation thicknesses were $0.11 \mathrm{~m}$, $0.08 \mathrm{~m}, 0.05 \mathrm{~m}$, and $0.06 \mathrm{~m}$, respectively. It is seen that the payback period depends on insulation thickness and insulation

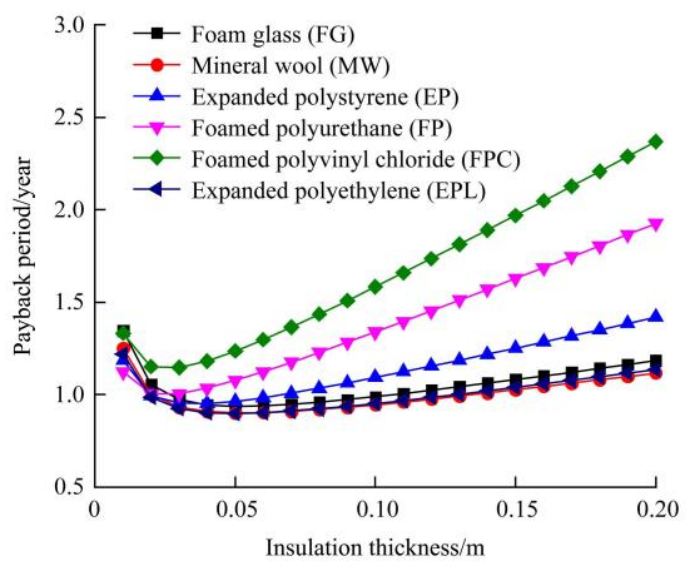

a. Harbin

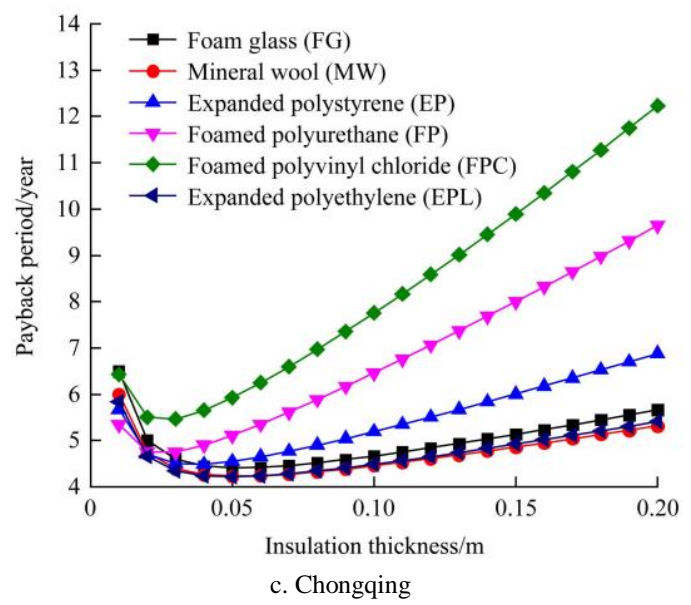

material. Ekici et al. ${ }^{[10]}$ also observed that the payback periods varied from 0.71 to 9.10 years, depending on the city, the type of wall, and insulation material. We note that applying different insulation materials in different climates is more costly whereas the payback period is shorter.

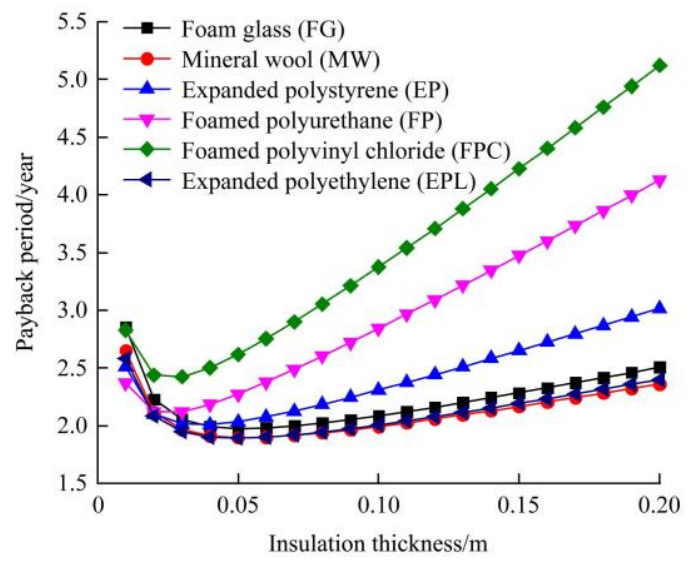

b. Beijing

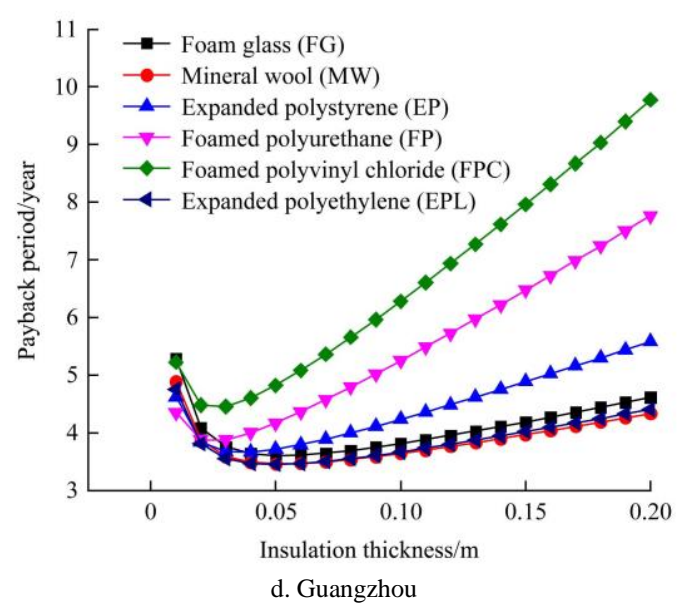

Figure 7 Effects of insulation thickness on payback period of laying hen houses with light color surface in selected five cities:

Harbin, Beijing, Chongqing, Guangzhou

\subsubsection{Optimum insulation thicknesses in five typical cities}

The optimum insulation thickness, LCS (the life cycle savings corresponding to the optimum insulation thickness), LCTC, and payback periods for light, mid, and deep color surface sandwich wall for the five cities are given in Tables 7-9 for finishing pig houses, and in Tables 10-12 for laying hen houses. The optimum insulation thicknesses for the sandwich structure livestock buildings external envelopes have been optimized, and the energy saving can be obtained by using proper insulation thicknesses in different regions, and the results can be also a useful tool for farmers. The results obtained that in future livestock buildings in
China needs to facilitate the energy saving and maintain a comfortable thermal environment for the animals, and to specify its energy requirement during winter and the selection of an adequate heating system during the design phase of a livestock building. However, the limitation of the study was that only six commonly used thermal insulation materials (foam glass, mineral wool, expanded polystyrene, foamed polyurethane, foamed polyvinyl chloride, and expanded polyethylene) were studied. Meanwhile, different animals have different demands on the thermal environment, which will affect energy consumption. Further research needs to be conducted in this area.

Table 7 Optimum insulation thickness, life cycle savings, life cycle total cost, and payback periods for various insulation types in light color surface envelopes of finishing pig houses in five cities

\begin{tabular}{|c|c|c|c|c|c|}
\hline \multirow{2}{*}{ Insulation type } & \multicolumn{5}{|c|}{ City } \\
\hline & Harbin & Beijing & Chongqing & Kunming & Guangzhou \\
\hline \multicolumn{6}{|c|}{ Optimum insulation thickness/m } \\
\hline Foam glass & 0.25 & 0.20 & 0.17 & 0.11 & 0.20 \\
\hline Mineral wool & 0.25 & 0.20 & 0.17 & 0.11 & 0.20 \\
\hline Expanded polystyrene & 0.17 & 0.13 & 0.12 & 0.08 & 0.14 \\
\hline Foamed polyvinyl chloride & 0.11 & 0.09 & 0.08 & 0.05 & 0.10 \\
\hline Expanded polyethylene & 0.24 & 0.19 & 0.16 & 0.11 & 0.19 \\
\hline
\end{tabular}




\begin{tabular}{|c|c|c|c|c|c|}
\hline \multirow{2}{*}{ Insulation type } & \multicolumn{5}{|c|}{ City } \\
\hline & Harbin & Beijing & Chongqing & Kunming & Guangzhou \\
\hline \multicolumn{6}{|c|}{ Life cycle total cost $(\mathrm{LCTC}) / \$ \cdot \mathrm{m}^{-2}$} \\
\hline Foam glass & 26.71 & 23.12 & 21.48 & 17.50 & 23.49 \\
\hline Mineral wool & 24.52 & 21.41 & 19.99 & 16.54 & 21.73 \\
\hline Expanded polystyrene & 27.54 & 23.76 & 22.05 & 17.86 & 24.15 \\
\hline Foamed polyvinyl chloride & 37.98 & 31.90 & 29.12 & 22.37 & 32.52 \\
\hline Expanded polyethylene & 24.42 & 21.33 & 19.92 & 16.49 & 21.65 \\
\hline \multicolumn{6}{|l|}{ Life cycle saving $(\mathrm{LCS}) / \$ \cdot \mathrm{m}^{-2}$} \\
\hline Foam glass & 218.3 & 129.4 & 96.06 & 34.00 & 137.5 \\
\hline Mineral wool & 220.5 & 131.1 & 97.55 & 34.96 & 139.3 \\
\hline Expanded polystyrene & 217.5 & 128.7 & 95.49 & 33.63 & 136.8 \\
\hline Foamed polyvinyl chloride & 207.0 & 120.6 & 88.42 & 29.13 & 128.5 \\
\hline Expanded polyethylene & 220.6 & 131.2 & 97.62 & 35.02 & 139.4 \\
\hline \multicolumn{6}{|l|}{ Payback period, years } \\
\hline Foam glass & 1.19 & 1.755 & 2.19 & 4.65 & 1.68 \\
\hline Mineral wool & 1.11 & 1.655 & 2.07 & 4.44 & 1.58 \\
\hline Expanded polystyrene & 1.22 & 1.79 & 2.24 & 4.73 & 1.71 \\
\hline Foamed polyurethane & 1.32 & 1.92 & 2.39 & 5.01 & 1.84 \\
\hline Foamed polyvinyl chloride & 1.59 & 2.29 & 2.82 & 5.81 & 2.19 \\
\hline Expanded polyethylene & 1.11 & 1.65 & 2.07 & 4.43 & 1.58 \\
\hline
\end{tabular}

Table 8 Optimum insulation thickness, life cycle saving, life cycle total cost and payback periods for various insulation types in mid color surface envelopes of finishing pig house in five cities

\begin{tabular}{|c|c|c|c|c|c|}
\hline \multirow{2}{*}{ Insulation type } & \multicolumn{5}{|c|}{ City } \\
\hline & Harbin & Beijing & Chongqing & Kunming & Guangzhou \\
\hline \multicolumn{6}{|c|}{ Optimum insulation thickness/m } \\
\hline Foam glass & 0.25 & 0.20 & 0.19 & 0.14 & 0.223 \\
\hline Mineral wool & 0.25 & 0.20 & 0.19 & 0.14 & 0.23 \\
\hline Expanded polystyrene & 0.17 & 0.14 & 0.13 & 0.09 & 0.156 \\
\hline Foamed polyurethane & 0.11 & 0.09 & 0.09 & 0.06 & 0.11 \\
\hline Foamed polyvinyl chloride & 0.18 & 0.10 & 0.09 & 0.06 & 0.11 \\
\hline Expanded polyethylene & 0.23 & 0.19 & 0.18 & 0.13 & 0.22 \\
\hline \multicolumn{6}{|c|}{ Life cycle total cost $(\mathrm{LCTC}) / \$ \cdot \mathrm{m}^{-2}$} \\
\hline Foam glass & 26.49 & 23.50 & 22.80 & 19.32 & 25.20 \\
\hline Mineral wool & 24.33 & 21.74 & 21.13 & 18.11 & 23.21 \\
\hline Foamed polyurethane & 30.03 & 26.38 & 25.53 & 21.28 & 28.46 \\
\hline Foamed polyvinyl chloride & 37.62 & 32.54 & 31.36 & 25.45 & 35.43 \\
\hline Expanded polyethylene & 24.23 & 21.66 & 21.06 & 18.06 & 23.12 \\
\hline \multicolumn{6}{|l|}{ Life cycle saving $(\mathrm{LCS}) / \$ \cdot \mathrm{m}^{-2}$} \\
\hline Foam glass & 212.3 & 137.8 & 122.6 & 59.00 & 178.4 \\
\hline Foam glass & 214.5 & 139.5 & 124.3 & 60.21 & 180.4 \\
\hline Mineral wool & 211.5 & 137.1 & 122.0 & 58.54 & 177.7 \\
\hline Expanded polystyrene & 208.8 & 134.9 & 119.9 & 57.04 & 175.2 \\
\hline Foamed polyurethane & 201.2 & 128.7 & 114.0 & 52.86 & 168.2 \\
\hline Foamed polyvinyl chloride & 214.6 & 139.6 & 124.3 & 60.26 & 180.4 \\
\hline \multicolumn{6}{|l|}{ Payback period, years } \\
\hline Foam glass & 1.22 & 1.66 & 1.83 & 3.14 & 1.38 \\
\hline Foamed polyurethane & 1.34 & 1.84 & 2.00 & 3.40 & 1.52 \\
\hline Foamed polyvinyl chloride & 1.62 & 2.19 & 2.37 & 3.97 & 1.83 \\
\hline Expanded polyethylene & 1.13 & 1.57 & 1.72 & 2.98 & 1.29 \\
\hline
\end{tabular}


Table 9 Optimum insulation thickness, life cycle saving, life cycle total cost and payback periods for various insulation types in deep color surface envelopes of finishing pig house in five cities

\begin{tabular}{|c|c|c|c|c|c|}
\hline \multirow{2}{*}{ Insulation type } & \multicolumn{5}{|c|}{ City } \\
\hline & Harbin & Beijing & Harbin & Kunming & Harbin \\
\hline \multicolumn{6}{|c|}{ Optimum insulation thickness/m } \\
\hline Mineral wool & 0.25 & 0.21 & 0.22 & 0.17 & 0.25 \\
\hline Expanded polystyrene & 0.17 & 0.15 & 0.15 & 0.12 & 0.17 \\
\hline Foamed polyurethane & 0.11 & 0.10 & 0.10 & 0.08 & 0.12 \\
\hline Expanded polyethylene & 0.23 & 0.20 & 0.20 & 0.16 & 0.24 \\
\hline \multicolumn{6}{|c|}{ Life cycle total cost $(\mathrm{LCTC}) / \$ \cdot \mathrm{m}^{-2}$} \\
\hline Foam glass & 26.46 & 24.16 & 24.39 & 21.35 & 26.92 \\
\hline Mineral wool & 24.31 & 22.31 & 22.51 & 19.87 & 24.71 \\
\hline Expanded polystyrene & 27.28 & 24.86 & 25.10 & 22.00 & 27.77 \\
\hline Foamed polyurethane & 29.99 & 27.19 & 27.47 & 23.76 & 30.56 \\
\hline Foamed polyvinyl chloride & 37.57 & 33.67 & 34.06 & 28.90 & 38.36 \\
\hline \multicolumn{6}{|l|}{ Life cycle saving $(\mathrm{LCS}) / \$ \cdot \mathrm{m}^{-2}$} \\
\hline Foam glass & 211.7 & 153.0 & 158.5 & 93.63 & 224.5 \\
\hline Mineral wool & 213.8 & 154.8 & 160.3 & 95.11 & 226.7 \\
\hline Expanded polystyrene & 210.8 & 152.3 & 157.7 & 93.07 & 223.6 \\
\hline Foamed polyurethane & 208.1 & 150.0 & 155.4 & 91.22 & 220.9 \\
\hline Foamed polyvinyl chloride & 200.5 & 143.5 & 148.8 & 86.08 & 213.1 \\
\hline Expanded polyethylene & 214.0 & 155.0 & 160.4 & 95.18 & 226.8 \\
\hline \multicolumn{6}{|l|}{ Payback period, years } \\
\hline Foam glass & 1.22 & 1.55 & 1.51 & 2.23 & 1.17 \\
\hline Mineral wool & 1.14 & 1.46 & 1.42 & 2.11 & 1.09 \\
\hline Expanded polystyrene & 1.28 & 1.58 & 1.54 & 2.28 & 1.19 \\
\hline Foamed polyurethane & 1.35 & 1.70 & 1.66 & 2.43 & 1.29 \\
\hline Foamed polyvinyl chloride & 1.62 & 2.03 & 1.98 & 2.87 & 1.56 \\
\hline
\end{tabular}

Table 10 Optimum insulation thickness, life cycle savings, life cycle total cost, and payback periods for various insulation types in light color surface walls of laying hen house in five cities

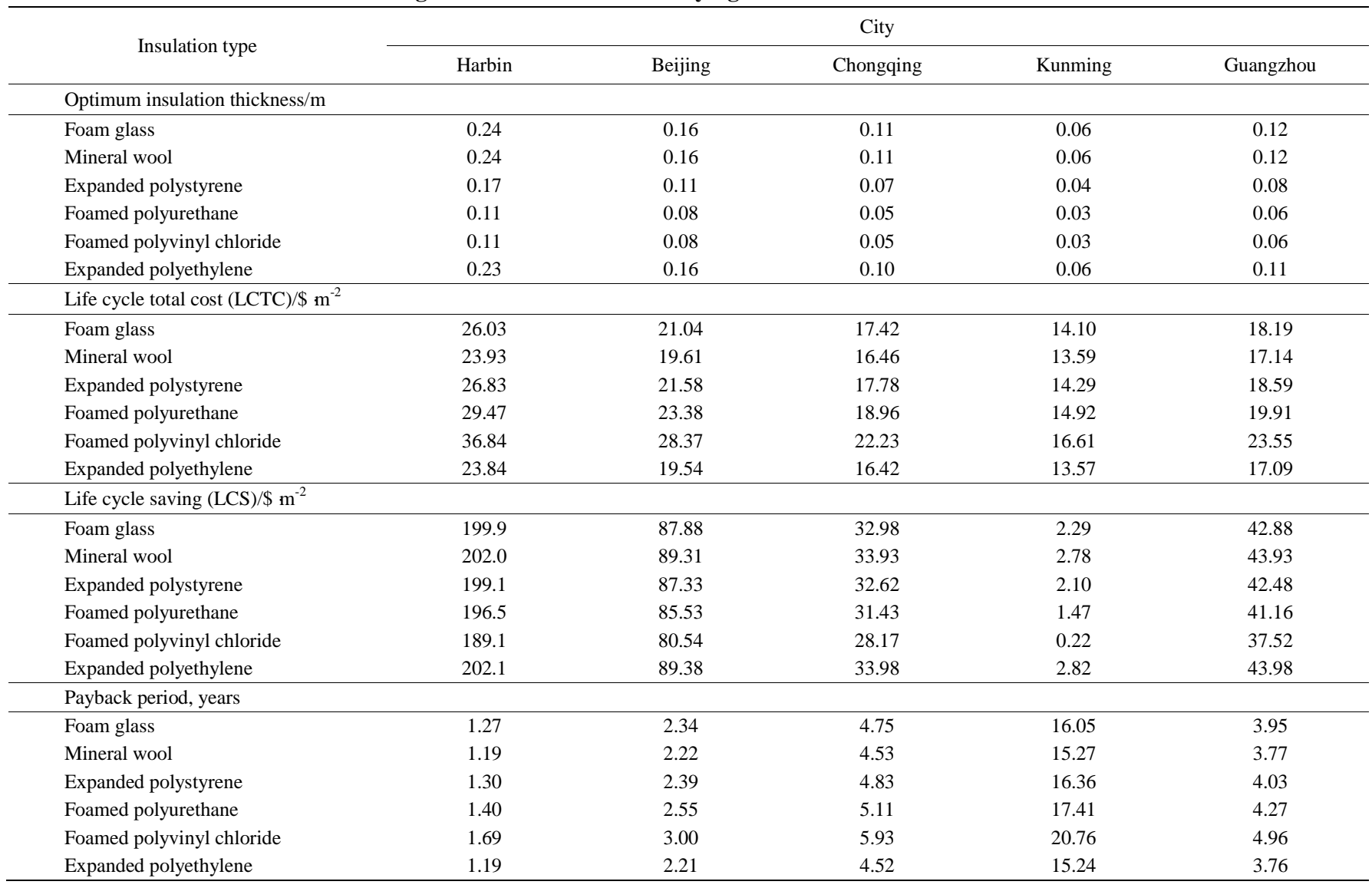


Table 11 Optimum insulation thickness, life cycle savings, life cycle total cost, and payback periods for various insulation types in mid color surface walls of laying hen house in five cities

\begin{tabular}{|c|c|c|c|c|c|}
\hline \multirow{2}{*}{ Insulation type } & \multicolumn{5}{|c|}{ City } \\
\hline & Harbin & Beijing & Chongqing & Kunming & Guangzhou \\
\hline \multicolumn{6}{|c|}{ Optimum insulation thickness/m } \\
\hline Foam glass & 0.23 & 0.16 & 0.13 & 0.05 & 0.15 \\
\hline Mineral wool & 0.23 & 0.16 & 0.13 & 0.06 & 0.15 \\
\hline Expanded polystyrene & 0.16 & 0.11 & 0.09 & 0.04 & 0.10 \\
\hline Foamed polyurethane & 0.11 & 0.07 & 0.06 & 0.02 & 0.07 \\
\hline Foamed polyvinyl chloride & 0.11 & 0.08 & 0.06 & 0.02 & 0.07 \\
\hline Expanded polyethylene & 0.22 & 0.15 & 0.12 & 0.05 & 0.14 \\
\hline \multicolumn{6}{|c|}{ Life cycle total cost $(\mathrm{LCTC}) / \$ \cdot \mathrm{m}^{-2}$} \\
\hline Foam glass & 25.26 & 20.90 & 18.47 & 13.87 & 20.12 \\
\hline Mineral wool & 23.27 & 19.48 & 17.38 & 13.39 & 18.81 \\
\hline Expanded polystyrene & 26.02 & 21.43 & 18.88 & 14.05 & 20.62 \\
\hline Foamed polyurethane & 28.53 & 23.21 & 20.24 & 14.64 & 22.27 \\
\hline Expanded polyethylene & 23.18 & 19.42 & 17.32 & 13.37 & 18.75 \\
\hline \multicolumn{6}{|l|}{ Life cycle saving $(\mathrm{LCS}) / \$ \cdot \mathrm{m}^{-2}$} \\
\hline Foam glass & 179.9 & 85.28 & 46.62 & 0.82 & 71.91 \\
\hline Mineral wool & 181.9 & 86.70 & 47.71 & 1.30 & 73.22 \\
\hline Expanded polystyrene & 179.2 & 84.75 & 46.20 & 0.64 & 71.41 \\
\hline Foamed polyurethane & 176.7 & 82.97 & 44.84 & 0.05 & 69.77 \\
\hline Foamed polyvinyl chloride & 169.7 & 78.05 & 41.07 & - & 65.21 \\
\hline Expanded polyethylene & 182.0 & 86.76 & 47.76 & 1.32 & 73.28 \\
\hline \multicolumn{6}{|l|}{ Payback period, years } \\
\hline Foam glass & 1.37 & 2.39 & 3.73 & 18.51 & 2.72 \\
\hline Mineral wool & 1.29 & 2.27 & 3.55 & 17.57 & 2.58 \\
\hline Expanded polystyrene & 1.41 & 2.44 & 3.79 & 18.86 & 2.77 \\
\hline Foamed polyurethane & 1.51 & 2.60 & 4.02 & 20.16 & 2.95 \\
\hline Foamed polyvinyl chloride & 1.82 & 3.07 & 4.68 & 24.32 & 3.46 \\
\hline
\end{tabular}

Table 12 Optimum insulation thickness, life cycle savings, life cycle total cost, and payback periods for various insulation types in deep color surface walls of laying hen house in five cities

\begin{tabular}{|c|c|c|c|c|c|}
\hline \multirow{2}{*}{ Insulation type } & \multicolumn{5}{|c|}{ City } \\
\hline & Harbin & Beijing & Chongqing & Kunming & Guangzhou \\
\hline \multicolumn{6}{|c|}{ Optimum insulation thickness/m } \\
\hline Foam glass & 0.22 & 0.17 & 0.15 & 0.08 & 0.18 \\
\hline Mineral wool & 0.22 & 0.17 & 0.15 & 0.08 & 0.18 \\
\hline Expanded polystyrene & 0.15 & 0.11 & 0.10 & 0.06 & 0.12 \\
\hline Foamed polyurethane & 0.10 & 0.08 & 0.07 & 0.04 & 0.08 \\
\hline Expanded polyethylene & 0.21 & 0.16 & 0.14 & 0.08 & 0.17 \\
\hline \multicolumn{6}{|c|}{ Life cycle total cost $($ LCTC $) / \$ \cdot m^{-2}$} \\
\hline Foam glass & 24.94 & 21.19 & 20.01 & 15.53 & 22.03 \\
\hline Mineral wool & 22.99 & 19.73 & 18.72 & 14.82 & 20.46 \\
\hline Expanded polystyrene & 25.68 & 21.74 & 20.50 & 15.79 & 22.62 \\
\hline Foamed polyurethane & 28.14 & 23.56 & 22.13 & 16.66 & 24.58 \\
\hline Foamed polyvinyl chloride & 35.00 & 28.63 & 26.63 & 19.02 & 30.05 \\
\hline \multicolumn{6}{|l|}{ Life cycle saving $(\mathrm{LCS}) / \$ \cdot \mathrm{m}^{-2}$} \\
\hline Foam glass & 171.8 & 90.61 & 70.08 & 13.19 & 106.7 \\
\hline Mineral wool & 173.8 & 92.07 & 71.38 & 13.90 & 108.2 \\
\hline Expanded polystyrene & 171.1 & 90.07 & 69.59 & 12.93 & 106.1 \\
\hline Foamed polyurethane & 168.7 & 88.24 & 67.97 & 12.06 & 104.1 \\
\hline Foamed polyvinyl chloride & 161.8 & 83.18 & 63.46 & 9.697 & 98.7 \\
\hline Expanded polyethylene & 173.9 & 92.14 & 71.44 & 13.93 & 108.3 \\
\hline \multicolumn{6}{|l|}{ Payback period, years } \\
\hline Foam glass & 1.42 & 2.29 & 2.77 & 8.40 & 2.03 \\
\hline Mineral wool & 1.34 & 2.17 & 2.63 & 8.03 & 1.92 \\
\hline Expanded polystyrene & 1.45 & 2.34 & 2.82 & 8.54 & 2.07 \\
\hline Foamed polyurethane & 1.56 & 2.49 & 3.00 & 9.03 & 2.21 \\
\hline Foamed polyvinyl chloride & 1.88 & 2.94 & 3.52 & 10.48 & 2.62 \\
\hline Expanded polyethylene & 1.33 & 2.161 & 2.62 & 8.01 & 1.91 \\
\hline
\end{tabular}




\section{Conclusions}

In this study, the optimum insulation thickness, LCTC, LCS, and the payback period of sandwich wall structures (color steel laminboard) of finishing pig houses and laying hen buildings of five different climate zone cities of China were analyzed based on the air degree-days method. The following conclusions can be drawn:

(1) The optimum insulation thickness increased with an increase in degree-days and thermal conductivity of the insulation materials. The maximum insulation thickness was obtained at higher degree-days using foam glass and mineral wool.

(2) The LCTC decreased initially and then increased gradually as insulation thickness increased due to the increasing cost of insulation materials.

(3) The type of insulation material had a large effect on LCS because these depend on the price of the insulation material. The LCS increased rapidly as insulation thickness increased, and then gradually levelled off as the insulation thickness reached its optimum value.

(4) The payback periods using foam glass and mineral wool as insulation were lower than that using foamed polyvinyl chloride as insulation. The payback period ranged from 0.89 to 2.36 years in Harbin, 1.89 to 5.12 years in Beijing, 4.22 to 12.23 years in Chongqing, and 3.45 to 9.77 years in Guangzhou.

\section{Nomenclature}

$C_{f} \quad$ Fuel cost, $\$ /(\mathrm{kW} \cdot \mathrm{h})$

$C_{i} \quad$ Price of insulation material, $\$ / \mathrm{m}^{3}$

$C_{\text {ins }}$ Insulation cost, $\$ / \mathrm{m}^{2}$

$d \quad$ Inflation rate

$E_{c}$ Annual energy consumption for cooling, $\mathrm{kW} /\left(\mathrm{m}^{2} \cdot \mathrm{a}\right)$, $\mathrm{m}^{3} /\left(\mathrm{m}^{2} \cdot \mathrm{a}\right)$, or $\mathrm{kWh} /\left(\mathrm{m}^{2} \cdot \mathrm{a}\right)$

$E_{h}$ Annual energy consumption for heating, $\mathrm{kW} /\left(\mathrm{m}^{2} \cdot \mathrm{a}\right)$, $\mathrm{m}^{3} /\left(\mathrm{m}^{2} \cdot \mathrm{a}\right)$, or $\mathrm{kWh} /\left(\mathrm{m}^{2} \cdot \mathrm{a}\right)$

I Interest rate

$L H V$ Lower heating value of the fuel, $\mathrm{J} / \mathrm{kW}, \mathrm{J} / \mathrm{kg}$, or $\mathrm{J} / \mathrm{m}^{3}$

$M_{s}$ Ratio of the annual maintenance and operation costs to the original cost

$N_{e} \quad$ Economic analysis period, year

$P_{1} \quad$ Life cycle energy

$P_{2} \quad$ Ratio of the life cycle expenditures from additional capital investment to the initial investment

$P_{c} \quad$ All other costs, $\$ / \mathrm{m}^{2}$

$Q_{c} \quad$ Annual cold loss per unit area, $\mathrm{MJ} /\left(\mathrm{m}^{2} \cdot \mathrm{a}\right)$

$Q_{h} \quad$ Annual heat loss, $\mathrm{MJ} /\left(\mathrm{m}^{2} \cdot \mathrm{a}\right)$

$q_{w} \quad$ Heat loss per unit area of envelope, $\mathrm{W} / \mathrm{m}^{2}$

$R_{i} \quad$ Inside envelope surface thermal resistance, $\mathrm{m}^{2} \cdot \mathrm{K} / \mathrm{W}$

$R_{\text {ins }}$ Thermal resistance of the insulation layer, $\mathrm{m}^{2} \cdot \mathrm{K} / \mathrm{W}$

$R_{o} \quad$ Outside envelope surface thermal resistance, $\mathrm{m}^{2} \cdot \mathrm{K} / \mathrm{W}$

$R_{v} \quad$ Ratio of the resale value at the end of the analysis period to the first cost

$R_{t w}$ Total wall thermal resistance, excluding the insulation layer resistance, $\mathrm{m}^{2} \cdot \mathrm{K} / \mathrm{W}$

$R_{w} \quad$ Thermal resistance of the composite sandwich wall materials without the insulation, $\mathrm{m}^{2} \cdot \mathrm{K} / \mathrm{W}$

$t_{i} \quad$ Indoor base temperature, ${ }^{\circ} \mathrm{C}$

$t_{s} \quad$ Solar-air temperature, ${ }^{\circ} \mathrm{C}$

$U$ Heat transfer coefficient of the external envelope, $\mathrm{W} /\left(\mathrm{m}^{2} \cdot \mathrm{K}\right)$

$x \quad$ Thickness of the insulation materials, $\mathrm{m}$
Greek symbol

$\eta_{c} \quad$ Energy efficiency ratio of the cooling system

$\eta_{h} \quad$ Efficiency of the heating system

$\lambda_{\text {ins }}$ Thermal conductivity of the insulation materials, $\mathrm{W} /(\mathrm{m} \cdot \mathrm{K})$

$\Delta U$ Difference between the heat transfer coefficient without insulation and with insulation, $\mathrm{W} /\left(\mathrm{m}^{2} \cdot \mathrm{K}\right)$

Subscript

$c \quad$ Cooling

$h \quad$ Heating

$i \quad$ Internal

$o \quad$ Outside

$s \quad$ Solar

Abbreviations

Air degree-days-DD

Air heating degree-days-SHDD

Air cooling degree-days-SCDD

Life cycle total cost-LCTC

Life cycle savings-LCS

\section{Acknowledgements}

This work was supported by National Key R\&D Program of China (2018YFD0500700) and the China Agricultural Research System (CARS-40).

\section{[References]}

[1] Al-Sanea S A, Zedan M F, Al-Hussain S N. Effect of thermal mass on performance of insulated building walls and the concept of energy savings potential. Applied Energy, 2012; 89(1): 430-442.

[2] Olgun M, Elik M Y, Polat H E. Determining of heat balance design criteria for laying hen houses under continental climate conditions. Building and Environment, 2007; 42(1): 355-365.

[3] Kaynakli O. A review of the economical and optimum thermal insulation thickness for building applications. Renewable and Sustainable Energy Reviews, 2012; 16(1): 415-425.

[4] Wang Y, Zheng W, Li B, Li X. A new ventilation system to reduce temperature fluctuations in laying hen housing in continental climate. Biosystems Engineering, 2018; 181: 52-62.

[5] Compiled by National Bureau of Statistics of China. China Statistics Yearbook 2017. China Statistics Press, 2017. (in Chinese)

[6] Yu J, Yang C, Tian L, Liao D. A study on optimum insulation thicknesses of external walls in hot summer and cold winter zone of China. Applied Energy, 2009; 86(11): 2520-2529.

[7] Wang Y, Zheng W, Shi H, Li B. Optimising the design of confined laying hen house insulation requirements in cold climates without using supplementary heat. Biosystems Engineering, 2018; 174: 282-294.

[8] Daouas N. A study on optimum insulation thickness in walls and energy savings in Tunisian buildings based on analytical calculation of cooling and heating transmission loads. Applied Energy, 2011; 88(1): 156-164.

[9] Wang Y, Li B. An optimized solar-air degree-day method to evaluate energy demand for poultry buildings in different climate zones. Frontiers of Agricultural Science and Engineering (FASE), 2019, https://doi.org/10.15302/J-FASE-2019289.

[10] Ekici B B, Gulten A A, Aksoy U T. A study on the optimum insulation thicknesses of various types of external walls with respect to different materials, fuels and climate zones in Turkey. Applied Energy, 2012; 92(2): 211-217.

[11] Bolattürk A. Optimum insulation thicknesses for building walls with respect to cooling and heating degree-hours in the warmest zone of Turkey. Building \& Environment, 2008; 43(6): 1055-1064.

[12] Duffie J A, Bechman W A. Solar energy and thermal process. New York: Wiley. 1991; pp.475-478.

[13] Kamaruzzaman S N, Edwards R, Zawawi E M A, Che-Ani A. Achieving energy and cost savings through simple daylighting control in tropical historic buildings. Energy and Buildings, 2015; 90: 85-93.

[14] Yu J, Tian L, Yang C, Xu X, Wang J. Optimum insulation thickness of residential roof with respect to solar-air degree-hours in hot summer and cold winter zone of China. Energy \& Buildings, 2011; 43(9): 2304-2313. 
[15] Zhao Y, Xin H, Shepherd T A, Hayes M D, Stinn J P. Modelling ventilation rate, balance temperature and supplemental heat need in alternative vs. conventional laying-hen housing systems. Biosystems Engineering, 2013; 115(3): 311-323.

[16] GB 50736-2012. Design code for heating ventilation and air conditioning of civil buildings. China Architecture and Building Press, 2012. (in Chinese)

[17] Bolattürk A. Determination of optimum insulation thickness for building walls with respect to various fuels and climate zones in Turkey. Applied Thermal Engineering, 2006; 26(11): 1301-1309.

[18] Costantino A, Fabrizio E, Ghiggini A, Bariani M. Climate control in broiler houses: A thermal model for the calculation of the energy use and indoor environmental conditions. Energy and Buildings, 2018; 169: $110-126$
[19] Mahlia T M I, Taufiq B N, Ismail, Masjuki H H. Correlation between thermal conductivity and the thickness of selected insulation materials for building wall. Energy and Buildings, 2007; 39(2): 182-187.

[20] Ucar A, Balo F. Effect of fuel type on the optimum thickness of selected insulation materials for the four different climatic regions of Turkey. Applied Energy, 2009; 86(5): 730-736.

[21] Li B, Shi Z. Engineering technology on equipped agriculture. Beijing: China Agricultural Press, 2005; pp.69-72, 114-118. (in Chinese)

[22] $\mathrm{Lu} \mathrm{Y}$. Handbook of heating and air conditioning design. China Architecture and Building Press, 1993. (in Chinese)

[23] Liu X, Chen Y, Ge H, Fazio P, Chen G, Guo X. Determination of optimum insulation thickness of exterior wall with moisture transfer in hot summer and cold winter zone of China. Procedia Engineering, 2015; 121: 1008-1015. 